\title{
Indonesian Traditional Arts Database: Future Legal Protection Act
}

\author{
M. Citra Ramadhan ${ }^{1}$, Ivan Lanovara ${ }^{2} \&$ Tan Kamello $^{1}$ \\ ${ }^{1}$ Faculty of Law, Universitas Sumatera Utara, Indonesia \\ ${ }^{2}$ Think Smart Technology Resources, Malaysia \\ Correspondence: P.L., Rika Fatimah, School of Management, Faculty of Economics and Business, Universitas Gadjah \\ Mada, Indonesia
}

Received: October 23, 2014 Accepted: November 3, 2014 Available online: December 1, 2014

doi:10.11114/smc.v2i2.598

URL: http://dx.doi.org/10.11114/smc.v2i2.598

\begin{abstract}
Indonesian traditional arts (TAs) are facing real threats. The threats include misappropriation and extinction. This reality is caused by the lack of a legal umbrella that provides legal protection for Indonesian TAs. This paper offers a legal protection system by using TA documentation stored in a database. A database built with a proper formulation can be used to protect TAs from possible threats. Related to the threat of misappropriation, a database can be used as: first, a protective tool against uses unapproved by the local community and to minimize the distribution of Intellectual Property (IP) to unauthorized parties; second, as a tool to prove the ownership of a TA and protect the Intellectual Property Rights (IPR) related to the ownership of the TA in a positive way. Concerning the threat of extinction, a database can be used as a tool for long-term conservation and a source of information for research and development. Social community has recognized the organizations as an important way to keep existing value of arts and culture. The paper is to explore the importance of databases importance and to identify how database shall be recommended as the legal protection of Indonesian Traditional Arts (TAs). The Traditional Arts Database (TAsD) could be done by using the integrated technology within the RFID and web based technology.
\end{abstract}

Keywords: traditional art, Indonesian, legal protection, technology, database

\section{Introduction}

The effect by being the multicultural country, Indonesia has many of arts that spread off from Sabang to Merauke. They symbolize something inseparable from the people's everyday life, taking and giving a meaning in social life (Sardjono, 2010). TAs are an important resource of knowledge to human life (Hawin, 2006), and they serve as a nation's identity as well. TAs are forms of culture accumulated for millions of years, which have been enormously useful for the survival of society until today. Unfortunately, with time, some TAs are being disregard, not only by the society but also by the Government.

\subsection{Misappropriation of Indonesian Traditional Arts (Indonesian TAs) Overview}

Recently, numbers of misappropriation cases of Indonesian TAs, not only on a national scale but also on an international scale. Having only a little effort, for instance, in a deliberate and unauthorized manner a party can register an Indonesian TA to the relevant institution in charge of Intellectual Property Rights (IPRs) to obtain legality over the TA ownership, and to have the exclusive right to control it. Furthermore, the party may prohibit the local community to use their TA, despite the fact they have been performing the TA since a long time ago.

Such a misappropriation case has happened several times. I Ketut Denny Aryasa (Kusumadara, 2011) was once detained by the police on the basis of an accusation that he plagiarized two motifs of jewelry, i.e. river stones and fleur (flower), which belonged to John Hardy Ltd, a company headquartered in Hong Kong. In the proceeding, it was proven that John Hardy Ltd owned the copyrights of more or less 800 other Indonesian traditional motifs. A similar thing happened to craftsmen in Jepara, who have become mere workers making Jepara woodcarvings (despite Jepara having always been famous for its woodcarving since long ago and woodcarving being the town's cultural identity), because the Jepara woodcarvings have been protected with exclusive copyrights and patents owned by business owners from Australia, Canada, and the United States. Meanwhile, a rattan furniture company in Cirebon was complaining about its small margin of profits because the rattan bending technique has been patented by an American business owner, so that local businessmen must pay royalty for using the rattan bending technique. Ironically, even on tempe (soybean cake), a 
Javanese traditional food product, there have been 19 patents, of which 13 belong to the United States and the other 6 to Japan (Purwaningsih, 2012). It is not impossible that in the future Indonesian people can no longer consume Indonesian-made tempe, although they have known the food product since a long time ago.

The above claims of course violate the economic and moral rights of the local community where the TA come from. Owning the economic right, the foreign company can enjoy the economic value of the TA, whereas the local community, the original TA owner, deserves more to get it. What is worse, the local community will have to pay if they want to use their own TA. As for the moral right, the local community is not recognized as the owner of their TA, while to them this ownership issue is more important than the economic and commercialization issues (Jaszi, 2010).

\subsection{Sources of Extinction Threat to the Indonesian Traditional Arts (Indonesian TAs)}

Indonesian Traditional Arts (Indonesian TAs) should develop progressively, just as how they have been developing from hundreds of years ago until today. Ironically, though, TAs are facing the threat of extinction now. The threat is actually generated by the current generation. Anderson et. al. (2008) discuss that many young people in traditional art groups see limited opportunities at a local level in terms of personal development, and thus tend to prefer the opportunities offered by education to pursue a career elsewhere, such as working at a plant, setting up a business, working as a professional, etc. In addition, talented young people are usually more interested in a mainstream kind of art that is developing such as pop music to video graph, and see traditional arts not yet appreciated and prestigious enough. Furthermore, to the male and especially female youths remaining in their art communities and probably experienced artists too, traditional arts are seen as a means to make a living or an additional source of livelihood that is not reliable or full of uncertainty.

Reports on extinction threats have come from many regions in Indonesia, such as Cirebon. The Head of the Agency of Culture, Tourism, Youth, and Sports of Cirebon District said that 28 of 40 Cirebon TAs have become nearly extinct, and two have already been. The 28 TAs consist of eight art categories, including six items from the gamelan category, one from theater, four from puppetry, one from music, five from dance, two from literature, one from fine arts, and eight from traditional performing art. As for the two extinct TAs are tonil, which is a form of theatrical art, and wayang catur from the puppetry category (Coordinating Minister for People Welfare, 2014).

As explained, the situation is a real threat and may blur out Indonesia's identity as a nation. The Indonesian ideology of Pancasila was created by the founding fathers based on strong elements in Indonesian culture. If some elements of the culture are no longer cherished in its home, either because they are not applicable anymore in daily life as they have been claimed as belonging to other people or because the people no longer care anymore, the nation may be ruining. Indonesia needs to be aware of this danger, so there must be a legal umbrella soon to preserve its TAs.

Furthermore, the oral culture in Indonesian society has resulted in the lack of TA documentation, while in fact documentation has the power to be a basis for a legal umbrella for TAs. Many local communities are becoming aware of the importance of documentation to counter threats such as misappropriation and extinction (Nurdin et. al., 2012). Considering its power, if such documentation is made comprehensively and stored in a database, it will surely be even more useful. As such, this paper will discuss how far a database can be useful in minimizing threats to TAs as what is happening in Indonesia.

Comprehensive and linkage to other field study regarding discussion on threat of extinction the Indonesian TAs, shall bring about not only discussion on the level of importance but also extended to recommended implementation of database to protect Indonesian Traditional Arts. The threat is not only from the outside the country, but also from the inside of Indonesia. Traditional art could possibly are harmed by forms of exploitation, which can lead permanent loss of irreplaceable property. These cultural are also could be harmed by transformation of their traditional setting and purposes differently from those who are originally created. These conditions have push for effective legal protection of folklore to give traditional communities and government control over the use and existing of folklore. In addition, Database system could be used to store large number information of TAs. On broader level, nationalist aspirations and the need to preserve TAs from onslaught of foreign culture also has a role. Therefore, aim of this study is to explore the importance of databases importance and to identify how database shall be recommended as the legal protection of Indonesian Traditional Arts (TAs). The Traditional Arts Database (TAsD) could be done by using the integrated technology within the RFID and web based technology

\section{Currently Existing Legal Instruments Failing to Provide Legal Protection for Indonesian Traditional Arts (Indonesian TAs)}

The subject of TA legal instruments is always associated to IPR legal protection. This association is based on the fact that the object exists within the area of human intellectuality. World Intellectual Property Organization (WIPO) defines IPRs as follows:

Intellectual property, very broadly, means the legal rights which result from intellectual activity in the industrial, 
scientific, literary and artistic fields. It refers to creations of the mind: inventions; literary and artistic works; and symbols, names and images used in commerce. Intellectual property is divided into two categories: Industrial Property and Copyright. Industrial Property includes patents for inventions, trademarks, industrial designs and geographical indications. Copyright covers literary works (such as novels, poems and plays), films, music, artistic works (e.g., drawings, paintings, photographs and sculptures) and architectural design. Rights related to copyright include those of performing artists in their performances, among others. Intellectual property rights are like any other property right. They allow creators, or owners, of patents, trademarks or copyrighted works to benefit from their own work or investment in a creation (WIPO, 2004).

The term of TAs has overlapping definitions and uses, such as traditional knowledge and traditional cultural expression, cultural heritage, folklore, etc. However, generally there are some characteristics that define TA, namely TAs are a form of knowledge that results from human intellectuality in a local community's traditional lifestyle, merging with the local community's identity, developing in a dynamic way, passed on from generation to generation, and a source of creativity. Therefore, the legal protection of Indonesia TA exists under an Intellectual Property Rights (IPR) legal umbrella.

However, looking at misappropriation cases as described before, it is clear that IPR legal instruments have failed to protect human intellectuality in TAs. The failures happen because of the difference in viewing human intellectuality. Human intellectuality in IPRs is seen as an asset that must generate economic profits. Anyone interested in using an intellectual product must obtain the necessary consent in the form of license and pay royalty. IPRs see that there is nothing in this world that does not have an owner. An object that initially has a common status can be assigned an ownership right when there is an element of human effort in the production. IPRs also see that humans are the center of the universe, whereas human intellectuality in TAs is viewed as a form of human service to the universe, which has supported human life. Traditional artists will feel happy if somebody wants to learn about their arts, although that person comes from outside of the local community that owns the TA. People not only have the right to use a common good, but also obliged to contribute to the sustainability of the good for the next generation. TAs see that humans are just a tiny part of the universe. For that reason the human intellectual types in IPRs and TAs is different.

Intellectuality in IPRs is individualistic and capitalistic, while in TAs it is communalistic and spiritualistic (Sardjono, 2007). Other factors that have prevented the IPR legal umbrella from providing legal protection for TAs are the elements of anonymity and novelty. TAs have been practiced by local communities since hundreds of years ago, so the original creators are impossible to find out. Likewise, concerning the novelty, TAs do not have the novelty aspect that is required by IPR legal instruments in order to provide protection, because TAs were used and developed slowly from the past, passed on for generations, in local communities (Damodaran, 2008). The differences have caused the failure of IPR legal instruments in providing legal protection for TAs. Therefore, no matter how hard the effort to combine the IPR legal instruments and legal protection for TAs, the result will not be satisfying (Torsen, 2008).

\section{Providing Legal Protection for Indonesian Traditional Arts (Indonesian TAs) using a Database}

Having legal protection for Indonesian Traditional Arts (Indonesian TAs), shall not only protect the arts themselves but also to the community and cultural sustainability. Therefore, the subtopic will explore three main discussions are traditional arts database is effective for protecting traditional arts; database for legal protection of Indonesian Traditional Arts (Indonesian TAs); and Traditional Arts Database (TAsD) for community based management.

\subsection{Traditional Arts Database is Effective for Protecting Traditional Arts}

Indonesia must quickly create a legal umbrella to protect local communities' TAs using a database. A database can be used as a legal umbrella if it documents and clearly describes TAs. The data should include the TA's attributes, distribution, IPR owner, practicing groups, custodian groups, and customary regulations related to the use of the TA (Robinson, 2007). Besides the above, WIPO has provided a format for the database so that it will be effective to protect TAs. Although specifically designed for biological science database, the format can be applied to the Indonesian TA database, of course with a few adjustments. Therefore, a database should at least contain information such as date/time; area/location where TA collection is being undertaken; information about the environment; indigenous peoples organizations or local communities involved; specific individuals involved; conditions or limitations imposed on the use of the collected TA (because of its sacred or secret nature, for instance); specific site and place where TA is being recorded; uses of the TA (including traditional names of plants, animals, organisms and local taxonomies); targeted species of plants (including wild species or cultivated, native varieties) or animals; forms of applications, or techniques; history of use; expected results; forms of verification; and current conservation conditions (in vitro, live cuttings, tissue cultures, seed banks, etc.) (WIPO, 2012).

The more Indonesian TAs are documented in a database, the more useful the database will be in preserving the TAs. India is an example of a country that has managed to document their TAs in a database. Officially, India has recorded 100,000 (one hundred thousand) TAs. This success is achieved with the following strategy: 
Under the Indian Biological Diversity Act, the National Biodiversity Authority is coordinating local People's Biodiversity Registers (PeBRs) across the country. At each local area the Biodiversity Management Committee (BMCs) must help facilitate the documentation of TK (Traditional Knowledge) related to biodiversity and its many facets. A National Workshop on People's Biodiversity Registers was held in June 2006. The compilation of PeBRs involves obtaining Prior Informed Consent (PIC) from local communities. In fact, each community controls the entire PeBR process, with the assistance of NGOs and the BMCs (National Biodiversity Authority, 2006). Only knowledge for which consent is granted is shared. Knowledge will be coded differentially depending upon the desire of the communities - some will be kept confidential (where it is considered secret or sacred knowledge) and some will be available to the public. At the discretion of the local communities, the information will be linked to a larger Indian Biodiversity Information System (IBIS).

The scale of this task is enormous, but the PeBRs development process has already reached a remarkable level of complexity. A working plan has been conceived for the development, by mid-2007, of rules (under the Biological Diversity Act), processes, technical measures (including development of the nationwide IBIS and incorporating open source People's Biodiversity Register Information Systems - PeBINFO), PeBRs Methodology Manuals for use at the BMC level and for the establishment of Technical Support Groups (including taxonomists and ecologists, expert farmers and computer scientists) amongst other measures (National Biodiversity Authority, 2006). As the PeBRs system is developed across India, it will provide important insights for the development of similar projects in other countries (Robinson, 2007).

This kind of strategy can be implemented by the Indonesian government by involving stakeholders, particularly local communities. They have a very important role in the documentation of TAs, determining the quality and quantity of the database. In terms of quality, stakeholders or local communities in particular can prevent inaccuracy in the documentation that may negatively impact the economic, social, cultural, and spiritual values for them, because it is they that know best about the characteristics their TA. As such, local communities must be given the right to always make sure how their TA is documented, so the quality of the documentation will always be maintained.

In terms of quantity, all stakeholders can increase the number of TAs documented by educating local communities on how important documenting TAs is for themselves. Oral tradition has always been strong in Indonesia, but now is the right time (considering the people's sharp reaction to the many TA misappropriation cases in Indonesia) to make people realize that their TAs have been useful for their lives.

\subsection{Database for Legal Protection of Indonesian Traditional Arts (Indonesian TAs)}

A database of Indonesian TAs up in a form that meets the requirements described before can be used optimally to provide a legal umbrella, so that the existence of Indonesian TAs is no longer threatened by misappropriation and extinction. Related to misappropriation, the database can be used to provide legal protection in a defensive and positive way.

Defensively, the database can be used as a tool to prevent uses unapproved by local communities and to avoid IPRs being given to unlawful parties. For an intellectual property to be registered at the authorized institution, it must have the element of novelty. As such, this database of Indonesian TAs can be used to show prior arts by the institution, so that if somebody registers an IP and it turns out the product is already registered as an Indonesian traditional art, the request will be rejected by the institution. A bigger step can be seen in India's decision to make agreements with some patent offices in a number of countries. The database may also be translated into many languages to make it accessible by the patent examiners at the offices. This is necessary to make sure that the database can provide information on traditional arts in both their modern and local names understandable by patent examiners (Amoji \& Kamble, 2013).

Positively, the database can be used as a means to show the ownership of TAs and protect IP rights related to the TA ownership. From a legal perspective, the database will make easier for the owner or certain rights related to the use of TAs in local communities to be recognized. The recognition will be very useful if the database used for defensive protection still fails to prevent misappropriation. In this kind of situation, where formal law requires evidence, the database can offer proofs that a TA has existed and been practiced by a local community for a certain use. Active steps, by submitting objection to the relevant IPR office or by filing a suit to court either national or international in the country where the misappropriation takes place, is very possible to do using IPR legal instruments with the principle of novelty. Therefore, IPR legal instruments are used in the opposite direction as they have usually been so far in the efforts of misappropriating Indonesian TAs.

Active action has also been taken by India in the case of Neem. Neem, Azadirachta (Pant \& Moorthy, 2013) has medical properties nearly in every part of the plant, which has traditionally been used by Indian people to cure various conditions such as cold, flu, malaria, skin diseases, fever, infection, and also in agriculture for its fungicide effect, while it is also known to be able to improve the body's immune system. In 1994, European Patent Office (EPO) awarded the 
patent right of Neem to WR Grace Company, a company based in the United States. The company used Neem oil as a fungicide for plants. In 1995, a group of international NGOs and Indian farmer representatives submitted a petition to EPO regarding the matter. In 2000, EPO revoked the patent right it had awarded to WR Grace Company on the basis that Neem had been known and used by Indian people for centuries.

\subsection{Traditional Arts Database (TAsD) for Community-Based Management}

In several of the study communities, traditional arts (TAs) and culture have long been accepted as an important part of regional identity (Directorate General for High Education, 2009). Traditional communities would have greater control over the use of their works and be able to demand compensation. Social community has recognized the organizations as an important way to keep existing value of arts and culture (Twarog, 2004). The social organization of traditional societies is based on a strong pattern of kinship groups as their basic constituent. Soetomo (2006) found that community-based management is a process that is integrated with the community effort itself that government authority in order to improve the socio-economic and cultural conditions of communities, to integrate community into the national life of the community and encourage more optimal contribution to improving the welfare of society, nation and state.

Therefore, Traditional Arts Database (TAsD) will be the umbrella to protect IPR through the communities. According to Radcliffe-Brown (1980), elements in communities could perpetuate this situation in long term. The culture will be endured through living process from activities in the communities. The links between museums, heritage and community are so complex that it is hard to distinguish which one leads the other - does heritage construct the community or does a community construct heritage? For many theorists, identifying community is about the recognition of shared characteristics, which are frequently grounded in an identifiable history, culture or landscape. In addition, they would say that communities need a common base, provided by history, heritage or experience in order to form (Crooke, 2008).

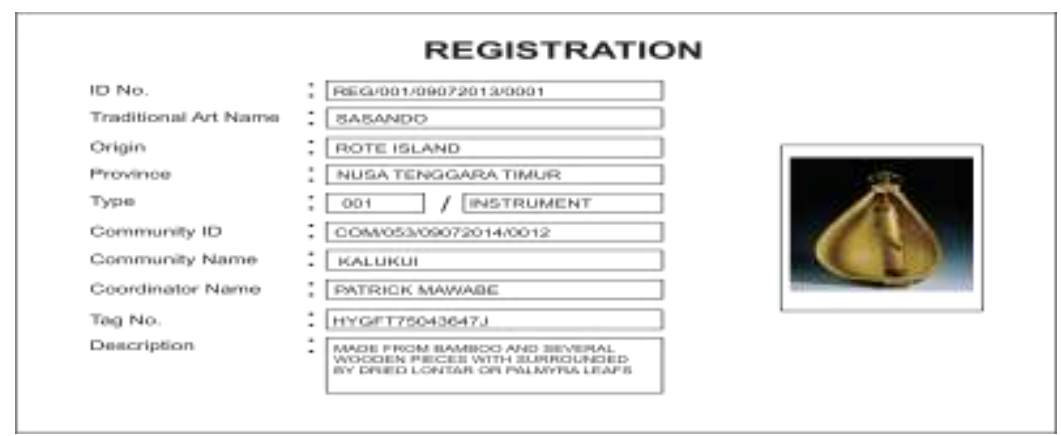

Figure 1. Registration of Indonesian Traditional Arts (Indonesian TAs) in TAs Database: The User Interfac.

Registration of TAs including of the origin where the traditional arts come and will be the part of traditional art identity (see Figure 1.). Community also will be registered and became certified to have license to play and keep the duplicate of traditional arts, especially for instrument type. Other community also could register same instrument after that particulars community are firstly registered. The registration form contain information such as type of traditional art, origin, community which have license to play the traditional art, and brief description about the traditional art. The registration will be arranged by government as the legal institution to manage and conserve of traditional arts. Government, in this issue is Department of Culture \& Tourism, will register all of traditional arts in all type such as instrument, song, dance, etc. and community which have commitment to manage traditional art are exist.

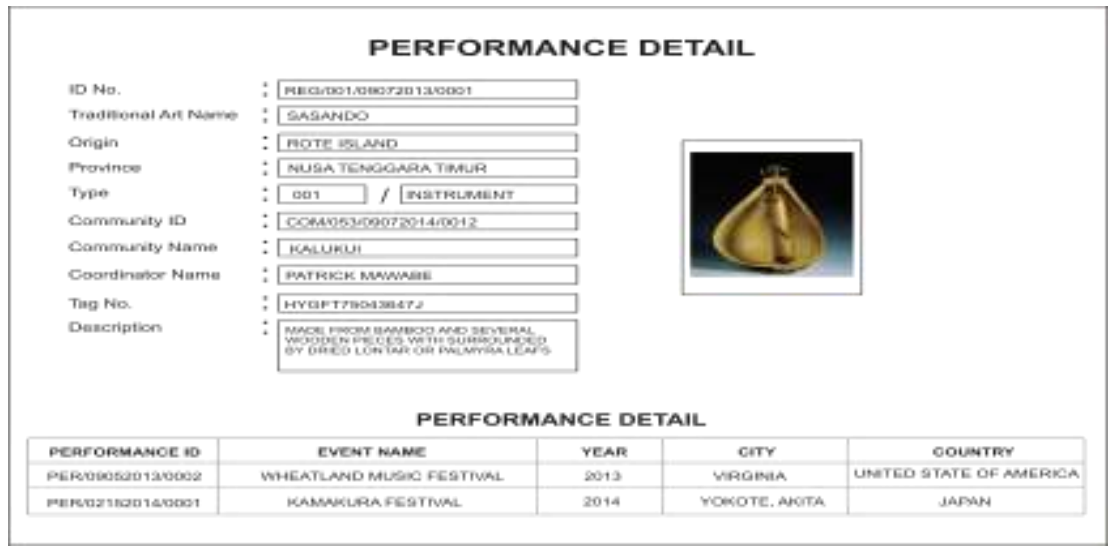

Figure 2. Performance Detail of Indonesian Traditional Arts (Indonesian TAs) in TAs Database:The User Interface. 
Traditional Arts Database could be used as effective and efficient performance history tracker for government or public to get information about community which has several traditional arts and the usage. Entering event information that has been done by a community and the traditional arts into the system, it would be known the event detail such as; place, country, event name, and year (see Figure 2). Furthermore, renewal information of TAsD into the system would keep the existence of traditional arts based management as one of important purpose of community.

\section{Rfid Technology as Future Plan in Legal Protection of Indonesian Traditional Arts (Indonesian TAs)}

TAsD will save all information about the arts including of all the types, history and the legal community which extinction of traditional arts either in original area or others by legal registration. Furthermore, TAsD could be done by using the integrated technology within the RFID and web based technology.

RFID technology will be one of the solutions to registries the Traditional Arts' information into an integrated system with website technology. All of Traditional Arts will be registries and the information including of name of Traditional Arts, location, province, history and date of the Traditional Arts. The website technology will be the 'gate' or 'portal' to open the information about the Traditional Arts.

Today most RFID data is transmitted within private corporate networks. The next step is to make this information available over the Internet to designated supply chain partners. This allows information on product movement to be exchanged with databases outside of a company's private network. For example, if an apparel supplier uses RFID-tagged containers, the RFID can track and store data about the containers' movement and contents (SKUs, serial numbers, etc.) in its systems and allow designated retail partners to pull the data into their own systems via the Internet (Atkinson, 2004).

\section{Conclusion}

A database can be used to protect TAs from possible threats. Related to the threat of misappropriation, a database can be used as a protective tool against uses unapproved by the local community and to minimize the distribution of IPs to unauthorized parties and as a tool to prove the ownership of a TA and protect the IP rights related to the ownership of the TA in a positive way. Concerning the threat of extinction, a database can be used as a tool for long-term conservation and a source of information for research and development.

Related to extinction, a database can be used as a tool for long-term conservation and as a source of information for research and development. TA documentation contained in the database will surely prevent Indonesian TAs from going extinct, because they are stored as national archives. Through this step, it is expected that the documented knowledge can be studied by future generation and made into lifestyle with modern adjustments.

Even more, if used optimally as a source of information for research and development, the database can help TAs develop as they have been since a long time ago until today. The development may be: One, related to product diversity. It is obvious that the thousands of batik motifs from different regions throughout Indonesia available in the database of traditional arts will drive traditional artists to create new products. Two, related to research based on empirical data on traditional arts. Indonesian TAs are currently difficult to track, so with the existence of the database, academicians who want to conduct a study do not need to spend a lot of money and to go a long way abroad to look for Indonesian TA data that have mostly been available in other countries, such as the Netherlands.

If Indonesia can consistently use a database in protecting TAs, Indonesia will be known as a country with a firm commitment in defending its rights. In addition, the firm commitment will surely discourage foreign individuals or companies to even submit an IPR claim over an Indonesian TA. Besides, the most important thing is Indonesia can form a cultural endurance, with which the feeling of nationalism will come along. The usage of database could be integrated by web based using the RFID technology. The website technology will be the 'gate' or 'portal' to open the information about the TAs.

\section{Acknowledgements}

This paper is presented in Workshop and Coaching on Writing Publication in International Journal (WCWPIJ) 2014, Malaysia. Therefore, the authors express their gratitude to TS Scholar for the event and Assoc. Prof. Dr. Rika Fatimah P.L., S.T., M.Sc., Ph.D. from Universitas Gadjah Mada for her valuable inputs during the preparation and improvement processes of this article.

\section{References}

Amoji, D. S., \& Kamble, V. T. (2013). Traditional Knowledge and Digital Library (TKDL): Protecting traditional Knowledge from Misappropriation in India. India Stream Research Journal, 3.

Anderson, et al. (2008). Traditional ARTSs: A Move towards Protection in Indonesia. Ford Foundation and American University. 
Atkinson, W. (2004). Web-Based RFID:Hype or Glimpse of the Future? [Article]. Retrieved from apparel.edgl.com/old-magazine/Web-Based-RFID-Hype-or-Glimpse-of-the-Future-64965.

Coordinating Minister for People Welfare (Menkokesra). (2014). Puluhan Kesenian Khas Cirebon Nyaris Punah [Article]. Retrieved from http://2010.menkokesra.go.id/content/puluhan-kesenian-khas-cirebon-nyaris-punah.

Crooke, E. M. (2008). Museums and community: ideas, issues, and challenges. USA and Canada: Routledge.

Damodaran, A. (2008). Traditional Knowledge, Intellectual Property Rights and Biodiversity Conservation: Critical Issues and Key Challenges. Journal of Intellectual Property Rights, 13.

Directorate General for High Education of the Republic of Indonesia (Dikti). (2009). Arsip Data Budaya itu Mutlak Arti Pentingnya!. Paper presented in workshop "Perencangan sistem arsip dan akses audio visual seni budaya".

Hawin, M. (2006). Perlindungan Pengetahuan Tradisional. Jurnal Berkala Fakultas Hukum Universitas Gadjah Mada. Indonesia: Yogyakarta.

Jaszi, P. (2010). Traditional Culture: A step forward for protection in Indonesia. Washington College of law Research Paper, No. 2010-16. American University Washington College of Law.

Kusumadara, A. (2011). Pemeliharaan dan Pelestarian Pengetahuan Tradisional dan Ekspresi Budaya Tradisional Indonesia: Perlindungan Hak Kekayaan Intelektual dan Non Hak Kekayaan Intelektual. Jurnal Hukum, 18(1).

Nurdin, R., et al. (2012). Traditional Knowledge Documentation: Preventing or Promoting Biopiracy. Petranika Journal of Social Science \& Humanities, 20(s), 11-22.

Pant, A., \& Moorthy, A. L. (2013). Knowledge management and safeguarding Indian Traditional knowledge. Annals of Library and Information Studies, 60(June).

Purwaningsih, E. (2012). Hak Kekayaan Intelektual dan Lisensi. Bandung: Mandar Maju.

Radcliffe-Brown, A. R. (1980). Struktur dan Fungsi dalam Maysrakat Primitif. Translate by E.E. Evans-Pritchard and Fred Eggan. Kuala Lumpur: Dewan Bahasa dan Pustaka.

Robinson, D. (2007). Exploring Components and Elements of Sui Generis Systems for Plant Variety Protection and Traditional Knowledge in Asia. International Centre for Trade and Sustainable Development (ICTSD).

Sardjono, A. (2007). The Development of Indonesian Intellectual Property Laws: Between Need and Reality. Japan External Trade Organization (IDE-JETRO), Japan: Institute of Developing Economies.

Sardjono, A. (2010). Hak Kekayaan Intelektual dan Pengetahuan Tradisional. Bandung: PT. Alumni.

Soetomo, S. (2006). Strategi-Strategi Pembangunan Masyarakat. Yogyakarta: Pustaka Pelajar

Torsen, M. (2008). Intellectual Property and Traditional Cultural Expression: Synopsis of Current Issues. Intercultural Human Right Law Review, 3.

Twarog, S. (2004). Preserving, Protecting and Promoting Traditional Knowledge: National Action and International dimension. UNCTAD.

WIPO. (2004). WIPO Intellectual Property Handbook: Policy, Law and Use.

WIPO. (2012). Traditional Knowledge Documentation Toolkit. The World Intellectual Property Organization.

\section{(cc) $\mathrm{BY}$}

This work is licensed under a Creative Commons Attribution 3.0 License. 